\title{
MAGMATISMO E TECTÔNICA DO ORÓGENO ARAÇUAÍ NO EXTREMO LESTE DE MINAS E NORTE DO ESPÍRITO SANTO $\left(18^{\circ}-19^{\circ} \mathrm{S}, 41^{\circ}-40^{\circ} 30^{\prime} \mathrm{W}\right)^{1}$
}

\author{
A.C. Pedrosa-Soares ${ }^{2}$, Cristiane Castañeda ${ }^{2}$, Gláucia Queiroga ${ }^{2}$, Camila Gradim² $^{2}$ Juliane Belém², $^{2}$ \\ Jorge Roncato ${ }^{2}$, Tiago Novo², Paulo Dias², Daniel Gradim², Sílvia Medeiros ${ }^{3}$, \\ Tânia Jacobsohn ${ }^{4}$, Marly Babinski ${ }^{4} \&$ Valter Vieira ${ }^{5}$
}

\begin{abstract}
This paper focuses on magmatic episodes and their relations to the main regional deformation in the backarc region of the Araçuaí Orogen (southeastern Brazil). The main tectonic event took place during the syncollisional stage (ca. 585-560 Ma) and imprinted the regional, solid-state foliation ( $\mathrm{Sn}$ ) in most rocks of this orogen. In the mapped region $\left(18^{\circ}-19^{\circ} \mathrm{S}, 41^{\circ}-40^{\circ} 30^{\prime} \mathrm{W}\right.$ ), the older unit (Nova Venécia Complex) occurs in small areas and consists of migmatitic, sillimanite-garnet-cordieritebiotite paragneisses with minor calcsilicate intercalations. The widespread garnet-biotite granites (Carlos Chagas, Montanha and Ataléia suites) are correlated to the syncollisional, S-type, G2 supersuite (ca. 585-560 Ma) of the Araçuaí Orogen, because they persistently record Sn, usually associated to striking mylonitic features. However, we also correlate some massifs of undeformed garnet-biotite granite to the Carlos Chagas Suite. Outwards from such undeformed pods, this Sn-free, garnet-biotite granite progressively shows solid-state deformation features superimposed on its igneous fabric, and gives place to the mylonitized granite typical of the Carlos Chagas Suite. In fact, both the undeformed and mylonitized granites of the Carlos Chagas Suite yielded similar magmatic crystallization ages (ca. 585-575 Ma; zircon, U-Pb SHRIMP). These G2 suites often show restites and xenoliths of paragneiss and calcsilicate rock, and gradational contacts with migmatitic inliers, suggesting a genesis related to anatexis of the Nova Venécia Complex. The usually small, irregular-shaped bodies and veins composed of garnet-cordierite leucogranites, free of Sn, belong to the post-collisional, S-type, G3 suite (ca. 540-530 Ma, in the focused region). Most G3 bodies are enveloped by and contain restites of foliated G2 granites, representing autochthonous to parautochthonous partial melts from the Carlos Chagas, Montanha and Ataléia suites. Sn-free granites and pegmatites, representing post-Sn partial melts from the Nova Venécia paragneisses, also can be correlated to the G3 suite. Very large to relatively small intrusions composed of biotite granite, charnockite and/or norite, free of Sn, represent the last magmatic episode of the Araçuaí Orogen, in the focused region. These intrusions (Aimorés Suite) belong to the post-collisional, I-type, G5 supersuite (ca. 520-490 Ma). Such a succession of magmatic episodes suggests that this middle crust sector of the Araçuaí Orogen remained hot $\left(\mathrm{T}>650{ }^{\circ} \mathrm{C}\right)$ for a long time interval (ca. $100 \mathrm{Ma}$ ), from ca. $585 \mathrm{Ma}$ to the Cambrian-Ordovician boundary. This requires a long-lasting release of orogenic heat that could be explained by a combination of three sources: i) heat input by convective asthenosphe under the backarc region from the precollisional to the syncollisional stages; ii) release of radiogenic heat from the crustal pile thickened by thrusts; and iii) ascent of mantle magmas and partial melting of the deep crust during the extensional collapse of the Araçuaí Orogen.
\end{abstract}

Keywords: deformation, granite, orogenic magmatism, Araçuaí Orogen

\section{INTRODUÇÃO}

O Orógeno Araçuaí localiza-se a leste do Cráton do São Francisco, entre os paralelos $15^{\circ}$ e $21^{\circ} \mathrm{S}$ (PedrosaSoares \& Wiedemann-Leonardos 2000, Pedrosa-Soares et al. 2001, 2005, Alkmimet al. 2006). O norte do Estado do Espírito Santo e extremo leste de Minas Gerais situamse na região de retroarco deste orógeno neoproterozóico-cambriano (Noce et al. 2004, PedrosaSoares et al. 2005).

Apesar de ser extremamente importante como produtora de granito ornamental, a região norte do Espírito Santo apenas contava com mapas de reconhecimento elaborados com esparsa informação de campo (Silva \& Ferrari 1976, Silva et al. 1987), trabalhos pioneiros de cunho geocronológico (Cordani 1973, Siga Jr. 1986) e compilações posteriores (e.g., Carta ao Milionésimo/GIS-Brasil da CPRM). O extremo leste de Minas Gerais foi mapeado na escala 1:100.000 pelo Projeto Leste (Pinto et al. 2001).

O presente artigo enfoca uma região dominada por rochas graníticas, situada entre $19^{\circ}-18^{\circ} \mathrm{S} \mathrm{e} 41^{\circ}-40^{\circ} 30^{\prime} \mathrm{W}$ (Figura 1), que foi coberta pelo mapeamento das folhas Mantena (SE-24-Y-A-VI) e Ecoporanga (SE-24-Y-A-III), escala 1:100.000, do Programa Geologia do BrasilContrato CPRM/UFMG (Castañeda et al. 2006, Gradim et al. 2006, Pedrosa-Soares et al. 2006). Como resultado 
do estudo de cerca de 1200 afloramentos rochosos, incluindo mais de uma centena de pedreiras, este artigo aborda as relações entre rochas plutônicas e deformação regional, visando correlações com os episódios magmáticos do Orógeno Araçuaí. Um critério fundamental, em análise de campo e microscópio, é a verificação da presença da foliação dúctil regional $(\mathrm{Sn})$ nos afloramentos estudados (ver explicações adiante). Obviamente, dados geocronológicos U-Pb são decisivos para se estabelecer idades e duração dos episódios magmáticos.

Utiliza-se os termos pré-colisional, sincolisional e pós-colisional, com conotação geotectônica, para relacionar os episódios magmáticos aos diversos estágios de evolução do Orógeno Araçuaí (e evitar termos dúbios, tais como, pré, sin e pós-tectônico).

A foliação regional $\mathrm{Sn}$ foi impressa como foliação de estado sólido (solid state foliation), sob temperaturas as mais diversas (desde fácies xisto verde a granulito), em rochas do Orógeno Araçuaí, durante o estágio sincolisional (ca. 585-560 Ma; e.g., PedrosaSoares et al. 2001, 2005, Heilbron et al. 2004, Silva et al. 2005, Alkmim et al. 2006; e muitas referências aí citadas). Por isto, os corpos graníticos pré-colisionais e sincolisionais registram Sn que, em geral, se superpõe concordantemente à orientação de fluxo ígneo. Entretanto, em grandes corpos graníticos pré- e sincolisionais podem restar partes poupadas total ou parcialmente da deformação, mas que passam progressivamente para termos deformados (granito foliado e variedades miloníticas). Por outro lado, os plútons pós-colisionais são sistematicamente livres da foliação Sn. Nas bordas de intrusões pós-colisionais, particularmente naquelas de grandes dimensões, podem ocorrer feições paralelas à foliação $\mathrm{Sn}$ das rochas encaixantes, tais como, fluxo ígneo e/ou foliação de borda, que poderiam ser confundidos com Sn. Além disso, as grandes intrusões tendem a conformar a foliação Sn das rochas encaixantes, moldando-a ao seu redor.

\section{MAGMATISMOETECTÔNICA}

As principais unidades que ocorrem na região enfocada estão representadas na Figura 1 (ver detalhes em Castañeda et al. 2006 e Pedrosa-Soares et al. 2006). Esta figura ilustra um fato marcante: rochas graníticas s.l., deformadas e indeformadas, ocupam mais de $90 \%$ da área mapeada. Além disso, quase dois terços desta região têm como substrato a Suíte Carlos Chagas, uma unidade extremamente homogênea em termos composicionais, mas estruturalmente heterogênea. A unidade mais antiga (Complexo Nova Venécia) e a mais nova (Grupo Barreiras) ocorrem em áreas restritas.

O Complexo Nova Venécia, que vem sendo caracterizado em detalhe por Gradim (em preparação), era considerado como parte do Complexo Paraíba do Sul (Silva et al. 1987). O Complexo Nova Venécia é constituído, essencialmente, por variedades de paragnaisse peraluminoso (kinzigítico), composto por proporções diversas de biotita, cordierita, granada e sillimanita, além de quartzo e feldspatos (Figura 1). Os minerais acessórios são grafita, pirita, monazita, apatita, zircão, titanita, hercinita e rutilo. A idade de sedimentação dos protolitos do Complexo Nova Venécia situa-se no intervalo 630-585 Ma (Noce et al. 2004). As associações mineralógicas das variedades de paragnaisse e rocha calcissilicática indicam metamorfismo na transição de fácies anfibolito-granulito. Dados quantitativos apontam temperatura metamórfica no intervalo 800$900^{\circ} \mathrm{C}$, à pressão de 5,5-6,5kb (Munhá et al. 2005, Castañeda et al., em preparação).

A intensa migmatização observada no Complexo Nova Venécia é representada pela grande quantidade de leucossoma quartzo-feldspático no paragnaisse (Figura 2). O episódio de fusão parcial mais antigo, sincinemático à principal fase de deformação dúctil regional, é registrado por leucossoma granítico portador da foliação regional $\mathrm{Sn}$. O melanossoma é xistoso e rico em biotita, granada e/ou cordierita e/ou sillimanita. Em meio ao migmatito destacam-se corpos graníticos maiores, foliados, com restos de paragnaisse e de rocha calcissilicática. Este episódio de fusão parcial é sincinemático à foliação $\mathrm{Sn}$ e se relaciona à granitogênese G2 (ver adiante). Além disso, veios graníticos e pegmatíticos, livres de $\mathrm{Sn}$, que cortam o complexo em direções variadas, evidenciam pelo menos um episódio mais jovem de fusão parcial. De fato, dados diversos indicam que o Complexo Nova Venécia permaneceu em temperatura compatível com anatexia granítica até o fim do Cambriano (e.g., Noce et al. 2004, Munhá et al. 2005, Jacobsohn 2006).

\section{GRANITOGÊNESEG2}

Os produtos da granitogênese $\mathrm{G} 2$ na região enfocada são representantes da Supersuíte G2 do Orógeno Araçuaí (Figura 1). Esta unidade reúne suítes, batólitos e outros corpos graníticos do tipo $\mathrm{S}$, que foram afetados pela deformação dúctil regional do estágio sincolisional do Orógeno Araçuaí, ou seja, registram a foliação Sn (Pedrosa-Soares \& Wiedemann-Leonardos 2000, Pedrosa-Soares et al. 2001, 2005). O acervo de dados geocronológicos indica que a Supersuíte G2 teve origem no intervalo 585-560 Ma (e.g., Nalini et al. 2000, Noce et al. 2000, Pedrosa-Soares \& Wiedemann-Leonardos 2000, Pedrosa-Soares et al. 2001, 2005, Silva et al. 2002, 2005, Heilbron et al. 2004, Martins et al. 2004). Silva et al. (2002) obteve a idade de 573 +/- 5 Ma (zircão, U-Pb SHRIMP) para granito foliado da Suíte Nanuque, representante da granitogênese G2 próximo ao limite norte da área mapeada.

Na região enfocada, os representantes da Supersuíte G2 são englobados nas suítes Ataléia, Carlos Chagas e Montanha, cujas denominações foram aplicadas, por Castañeda et al. (2006), Gradim et al. (2006) e PedrosaSoares et al. (2006), a partir das definições de Silva et al. (1987) e Pinto et al. (2001).

A Suíte Ataléia é composta de biotita granito e granada-biotita granito, foliados, que apresentam 


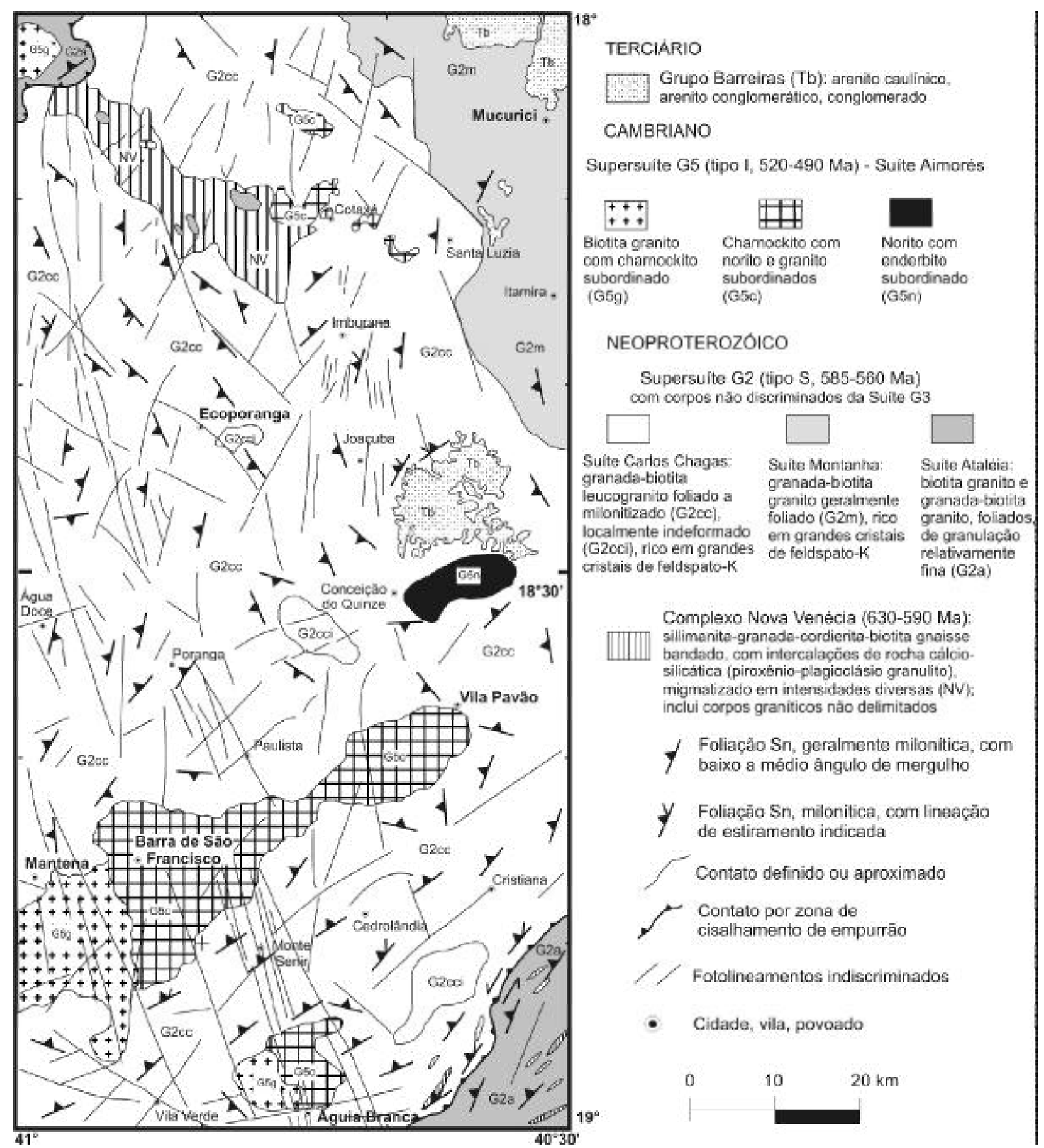

Figura 1. Mapa geológico simplificado da região do Orógeno Araçuaí entre $19^{\circ}-18^{\circ} \mathrm{S}$ e $41^{\circ}-40^{\circ} 30^{\prime} \mathrm{W}$, extremo leste de Minas Gerais e norte do Espírito Santo (modificado de Castañeda et al. 2006 e Gradim et al. 2006).

granulação fina e tons de cinza mais escuros (relativamente às rochas predominantes nas suítes Carlos Chagas e Montanha). A associação de campo dos granitos Ataléia com o Complexo Nova Venécia é marcante e pode ser verificada até mesmo em escala de mapa (Figura 1, ver lentes do Complexo Nova Venécia no interior da Suíte Ataléia, no canto sudeste do mapa). Esta associação também se revela pela presença de restitos, xenólitos e roof-pendants de rochas do Complexo Nova Venécia no granito Ataléia, assim como pela frequiência de corpos de granito Ataléia em meio aos paragnaisses Nova Venécia (Figura 1, ver corpos de granito Ataléia no Complexo Nova Venécia, no quadrante noroeste do mapa). A matriz das rochas da Suíte Ataléia se classifica como monzogranito no diagrama QAP (Figura 3). Localmente ocorrem termos protomiloníticos a miloníticos, com porfiroclastos de feldspato potássico pertítico e granada. A composição essencial consiste de quartzo, feldspato potássico, plagioclásio sódico e biotita. Granada, zircão, sillimanita, cordierita, apatita, monazita e minerais opacos são acessórios. A foliação regional Sn é materializada principalmente pela orientação da biotita e estiramento dos minerais félsicos (Figura 2). Dados geotermométricos quantitativos indicam que a foliação Sn originou-se à temperatura em torno de $640^{\circ} \mathrm{C}$ 

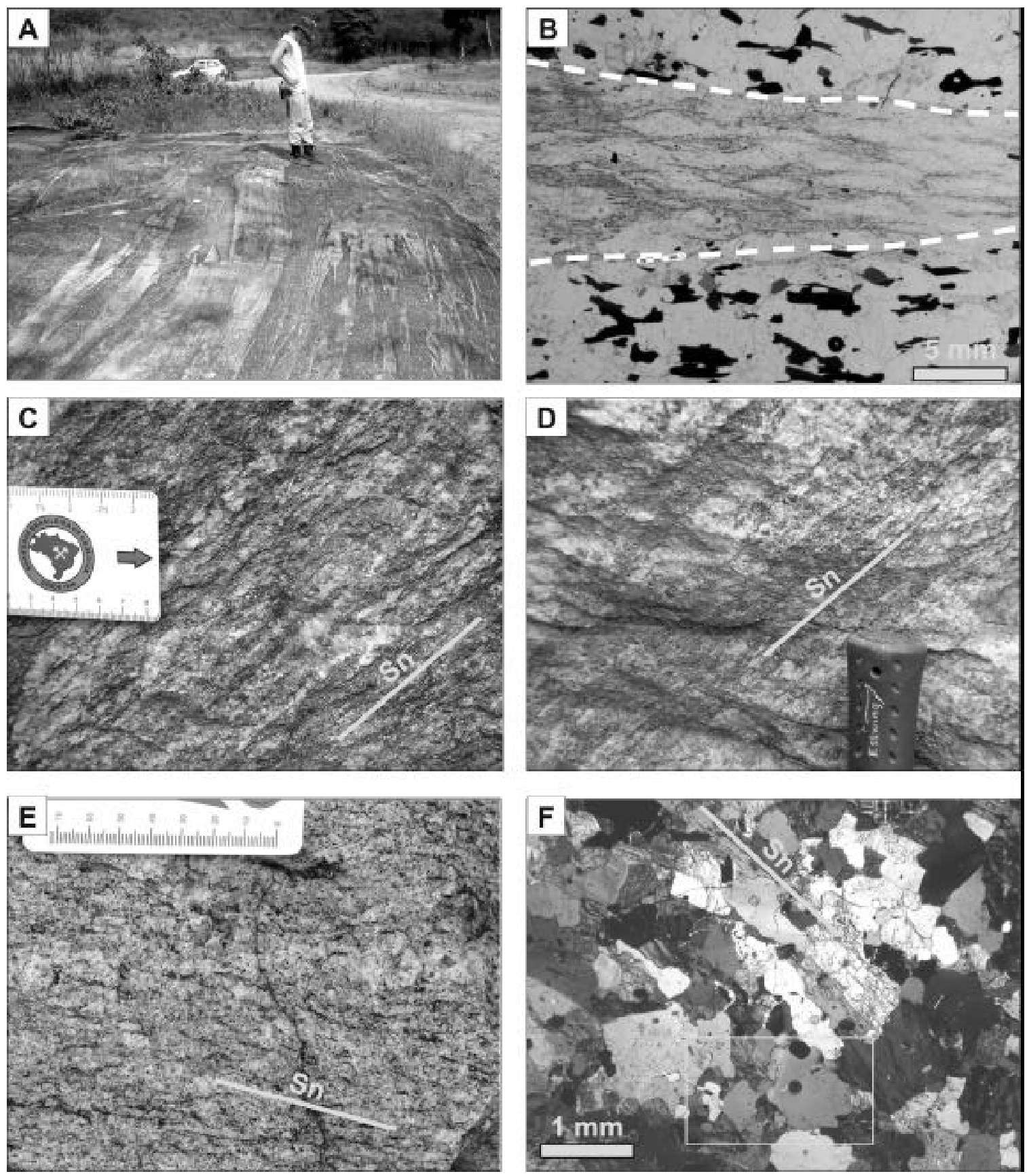

Figura 2. Rochas do Complexo Nova Venécia e Suíte Ataléia, aflorantes nas folhas Ecoporanga e Mantena: A, paragnaisse migmatítico; B, lâmina delgada de paragnaisse, mostrando poiquiloblasto de cordierita (entre as linhas tracejadas) estirado paralelamente a Sn e rico em inclusões orientadas de fibrolita, quartzo e feldspato; C e D, migmatitos de paragnaisse com intensidades diferentes de fusão parcial concordante com a foliação Sn; E, granito foliado da Suíte Ataléia; F, lâmina delgada do granito foliado Ataléia, mostrando o estiramento de quartzo, feldspato e biotita em Sn, e microagregados de minerais félsicos granoblásticos com junções tríplices,

evidenciando a recristalização sob deformação dúctil; no destaque, contatos irregulares (lobados) entre quartzo e feldspato, sugestivos de fase ígnea.

(Castañeda et al., em preparação). Xenólitos e restitos, de dimensões as mais variadas, constituídos por paragnaisse ou rocha calcissilicática são muito comuns e se encontram estirados segundo Sn. Veios e bolsões de leucogranito a granada e/ou cordierita, livres da foliação regional, cortam o granito foliado Ataléia e representam fusões tardias, correlacionáveis à granitogênese G3 (ver adiante).

Corpos da Suíte Ataléia apresentam contato gradacional com o Complexo Nova Venécia. Este tipo de contato é representado pelo aumento de intercalações de paragnaisse no granito (Figura 2). No quadrante sudeste da área (Figura 1), o contato da Suíte Ataléia com a Suíte Carlos Chagas é uma zona de cisalhamento 


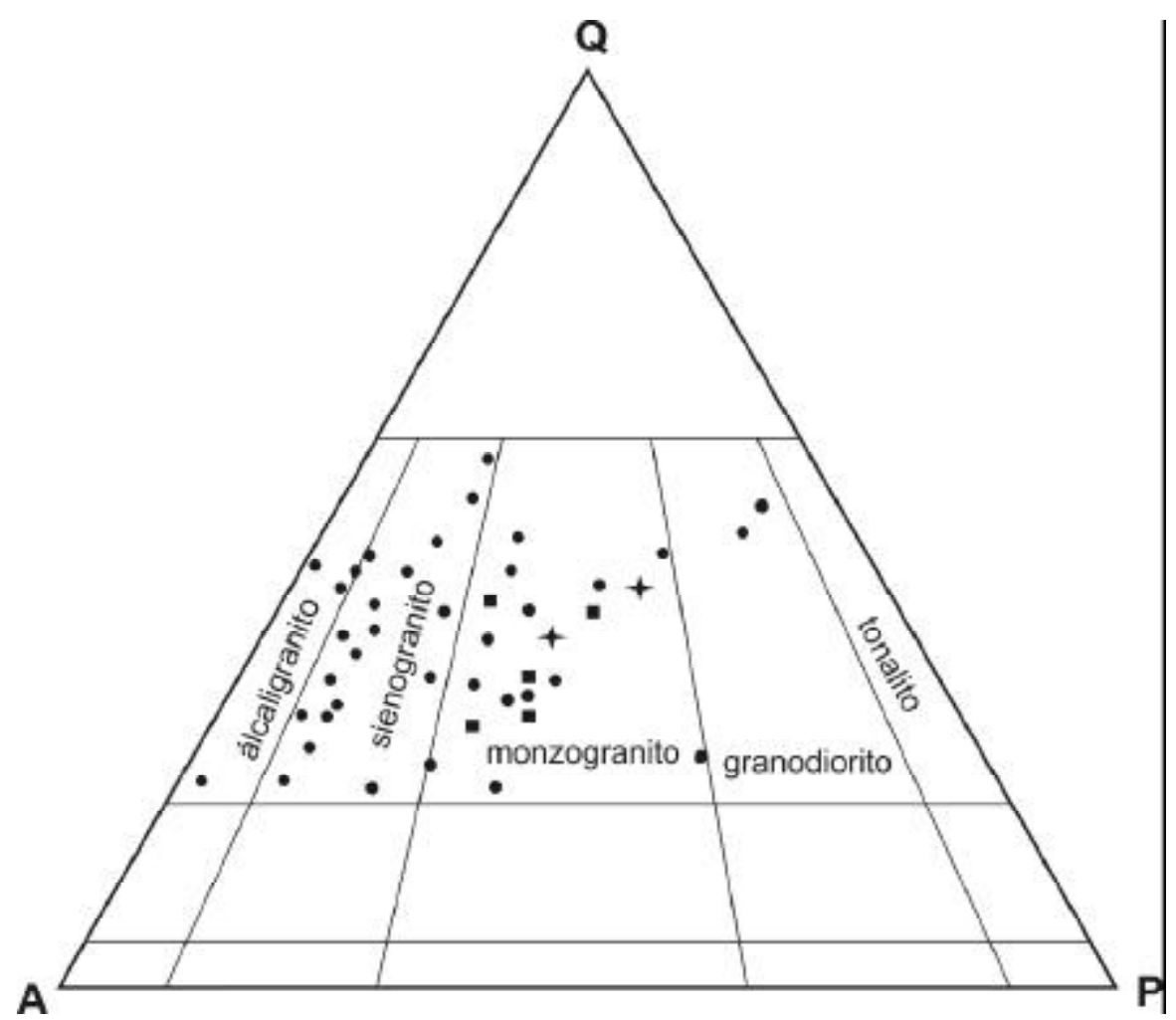

Figura 3. Composição modal da matriz de rochas graníticas da Supersuíte G2, na área enfocada: quadrado, Suíte Ataléia; círculo, Suíte Carlos Chagas; estrela, Suíte Montanha.

dúctil oblíqua, transpressional, de direção NE-SW, sinistral, com componente de empurrão indicador de transporte da capa para sudeste (i.e., a Suíte Carlos Chagas cavalga a Suíte Ataléia rumo a SE). Esta zona de cisalhamento é balizada por afloramentos de granito intensamente milonitizado, pertencente à Suíte Carlos Chagas (Figura 5).

A Suíte Carlos Chagas é regionalmente muito extensa, tem marcante homogeneidade composicional e registra a foliação $\mathrm{Sn}$, com marcantes feições protomiloníticas a miloníticas, em quase toda a sua área de exposição. Trata-se de uma unidade de rochas graníticas leucocráticas, do tipo $\mathrm{S}$, com granada e biotita onipresentes. Por aproximação, estas rochas ajustamse à definição de leucogranito (i.e., granito com baixo conteúdo de minerais máficos, geralmente menor que 5\%), embora sejam livres de moscovita magmática. A Suíte Carlos Chagas contêm xenólitos de paragnaisse e de rocha calcissilicática, cuja quantidade e tamanho aumentam próximo ao contato com o Complexo Nova Venécia.

A Suíte Carlos Chagas foi dividida em duas subunidades (Castañeda et al. 2006, Gradim et al. 2006, Pedrosa-Soares et al. 2006). A subunidade predominante em área, que contém as rochas deformadas da suíte, é assinalada com a sigla G2cc (Suíte Carlos Chagas deformada, Figura 1). A subunidade com trama ígnea bem preservada, muito menos expressiva em área, recebe a sigla G2cci (Suíte Chagas indeformada). As rochas predominantes nestas subunidades apresentam coloração branco-acinzentada, quando não intemperizadas. $\mathrm{O}$ intemperismo confere as tonalidades amarelas que incrementam o valor destas rochas como material ornamental.

Os dados disponíveis sugerem que as subunidades da Suíte Carlos Chagas apresentam a mesma idade de cristalização magmática. A datação U-Pb (zircão, SHRIMP) de uma amostra de granada-biotita granito sem deformação indica idade de cristalização magmática em torno de $576 \mathrm{Ma}$ (Gradim, em preparação). Por seu turno, um granada-biotita leucogranito milonitizado forneceu idade U-Pb SHRIMP (zircão) similar à das partes indeformadas desta suíte ( $c a .575 \mathrm{Ma}$; Jacobsohn 2006). Ambas as amostras da Suíte Carlos Chagas foram coletadas em afloramentos situados na Folha Mantena.

A composição da matriz das rochas da Suíte Carlos Chagas mostra grande dispersão no diagrama QAP, em decorrência da imprecisão imposta pela granulação grossa às análises modais (Figura 3). Contudo, a marcante quantidade de grandes cristais de feldspato potássico, em relação à matriz, indica que a melhor classificação para a composição total da rocha predominante na suíte é sienogranito (deformado ou não).

A subunidade G2cci (Suíte Chagas indeformada) representa as porções preservadas da deformação regional, sem foliação $\mathrm{Sn}$, onde são inequívocas as texturas e estruturas ígneas (Figura 4). A subunidade é constituída por biotita-granada leucogranito porfirítico de granulação muito grossa a grossa. Esta rocha é rica em grandes fenocristais euédricos de feldspato potássico pertítico e granada. Ocorre orientação por fluxo ígneo, com feições de entelhamento de fenocristais de feldspato retangulares e desvios de trajetória em 
torno de fenocristais maiores, assim como estrutura completamente isotrópica (Figura 4). A matriz do leucogranito tem granulação média a grossa e é constituída essencialmente por quartzo, feldspato potássico, plagioclásio sódico, granada e biotita. Os minerais acessórios são opacos (sulfeto e outros), zircão, apatita e monazita.

A subunidade G2cc (Suíte Chagas deformada) predomina largamente em toda a região de ocorrência da Suíte Carlos Chagas, inclusive além dos limites da área aqui focalizada (Pinto et al. 2001). O mapeamento das folhas Mantena e Ecoporanga, bem como os perfis regionais realizados pelos autores e informações de trabalhos já citados, demonstram que a deformação regional na Suíte Carlos Chagas é predominantemente milonítica e está registrada pela foliação dúctil Sn ( solid
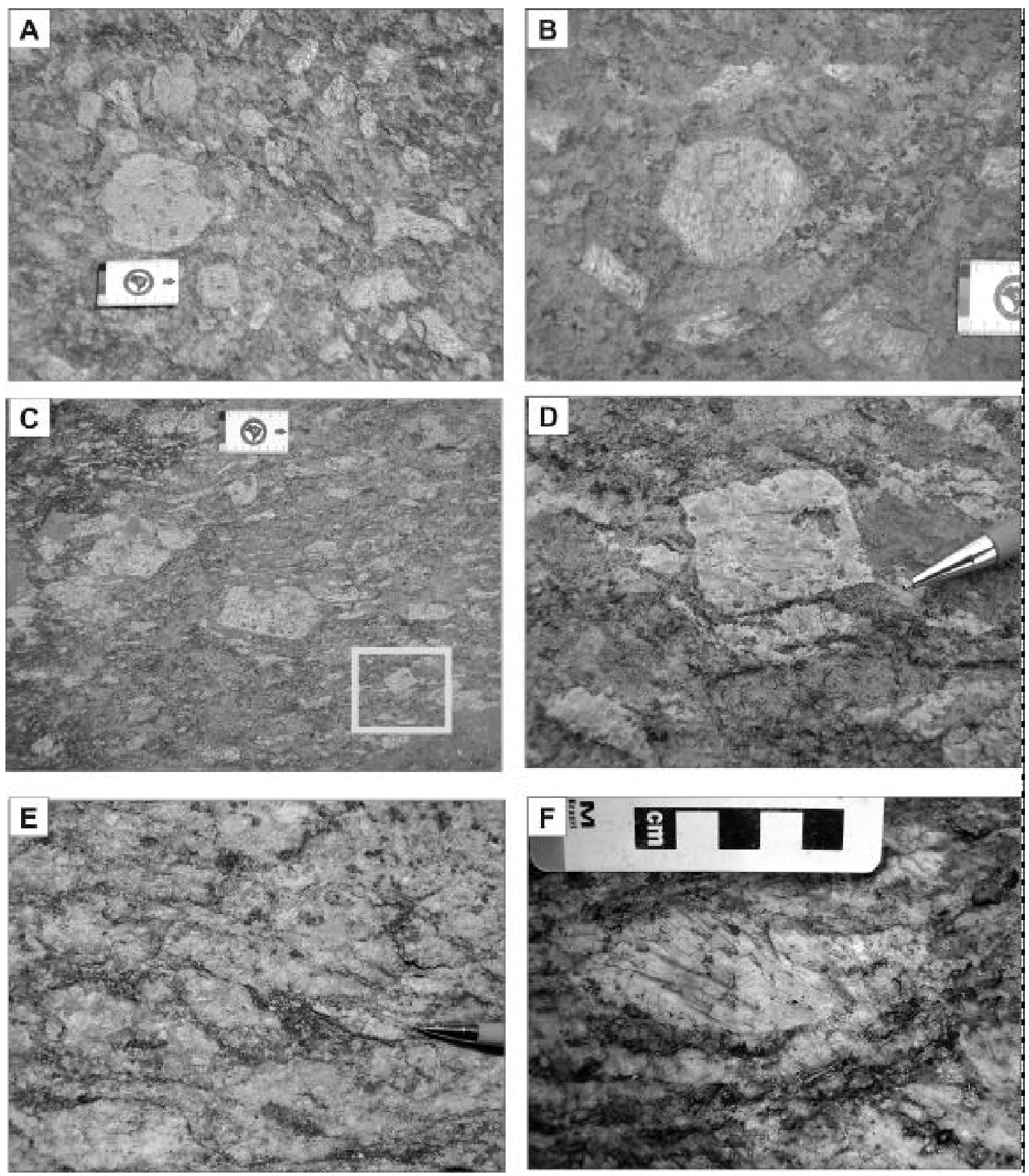

Figura 4. Fotografias da Suíte Carlos Chagas em afloramentos situados na Folha Mantena. A e B, ilustram feições ígneas muito bem preservadas (G2cci) na Serra da Invejada. Em A observa-se o sienogranito porfirítico com estrutura isotrópica e fenocristais de feldspato potássico caoticamente dispostos.

$B$ mostra desvio do fluxo ígneo (fenocristais retangulares) em torno do fenocristal maior. $C$ e D ilustram o início da deformação em estado sólido, ainda que em presença de quantidade significativa de fase líquida, quando a foliação Sn começou a se formar paralelamente ao fluxo ígneo (D ilustra o detalhe indicado em C).

E e F mostram o estágio protomilonítico, no qual grandes cristais de feldspato potássico tornam-se porfiroclastos ocelares sigmoidais, orientados ao longo da foliação Sn (subunidade G2cc). 
state foliation). As rochas que predominam na subunidade G2cc são termos miloníticos resultantes da deformação do leucogranito Carlos Chagas, em particular sillimanita-granada-biotita protomilonito-gnaisse e sillimanita-granada-biotita milonito-gnaisse, com sillimanita-granada ultramilonito muito subordinado (Castañeda et al. 2006, Pedrosa-Soares et al. 2006). De fato, as rochas desta subunidade são produtos da deformação milonítica progressiva do granada-biotita leucogranito rico em fenocristais centimétricos de feldspato potássico, originalmente orientados por fluxo ígneo (Figuras 4, 5 e 6). A deformação dúctil regional transformou os fenocristais em porfiroclastos ocelares, sigmoidais e/ou fitados ( ribbons). A foliação milonítica é geralmente anastomosada e se materializa pela orientação de biotita e sillimanita, e pelo estiramento de feldspato, quartzo e granada.

O protomilonito-gnaisse apresenta textura porfiroclástica grossa a muito grossa e é rico em porfiroclastos de feldspato potássico pertítico e granada, que podem exibir caudas de recristalização e/ou sombras de pressão, geralmente assimétricas (Figura 4 e 5). A matriz do protomilonito-gnaisse é essencialmente constituída de feldspato potássico pertítico, quartzo, plagioclásio sódico, granada, biotita e sillimanita. A foliação $\mathrm{Sn}$ é marcada pela orientação de biotita e
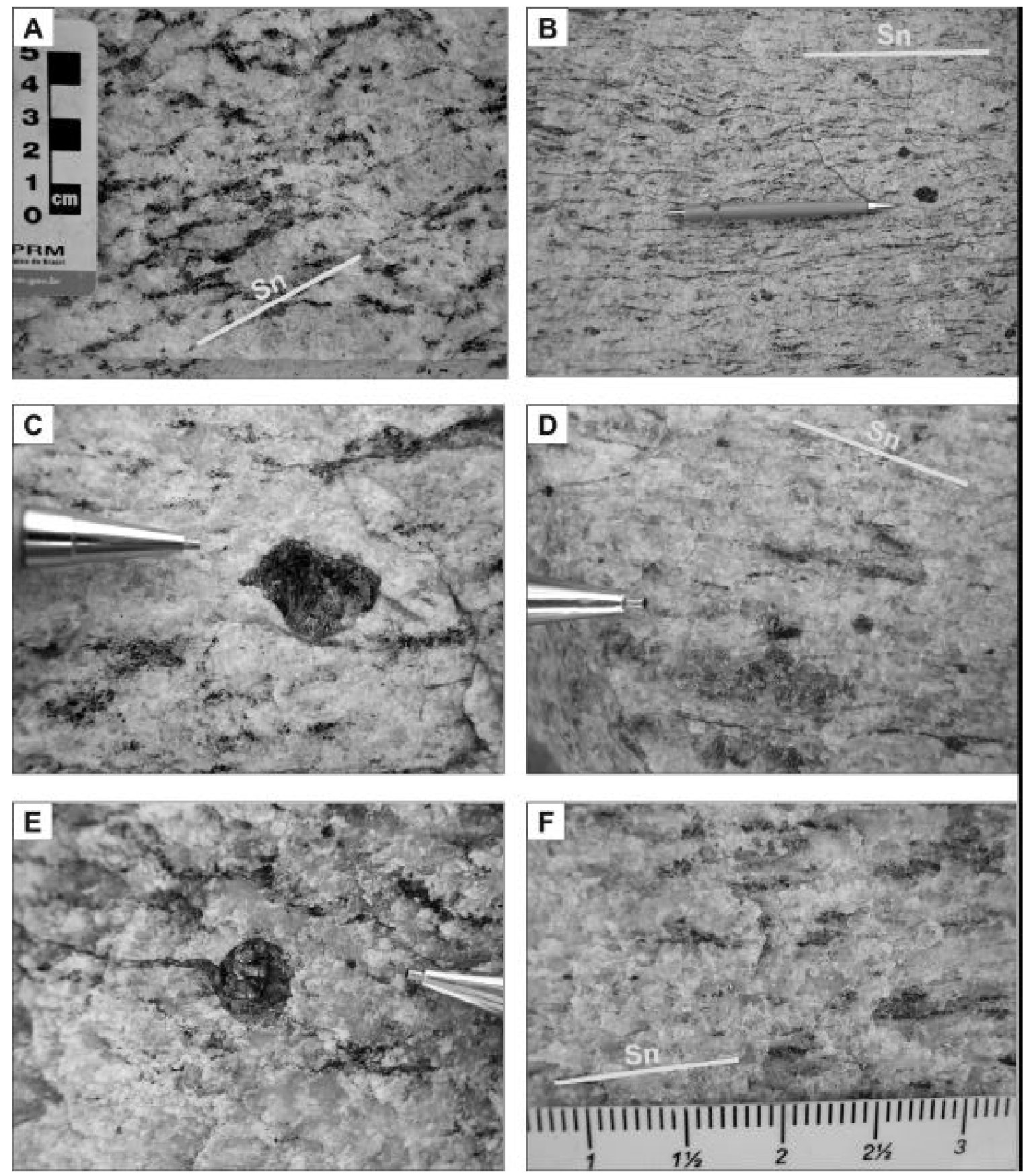

Figura 5. A seqüência de fotos mostra o incremento da deformação milonítica, desde milonito gnaisse (A e B) até ultramilonito gnaisse ( $D$ e F), em afloramentos da Folha Mantena. As fotos $C$ e E ilustram detalhes dos porfiroclastos de granada como indicadores cinemáticos. 
sillimanita, entre os porfiroclastos estirados de feldspato (Figura 6). Extinção ondulante é comum em quartzo e feldspato; o último também apresenta deformação de maclas. Ocorrem sillimanita fibrosa e prismática, como produto de substituição da biotita. Os minerais acessórios são opacos (sulfeto e magnetita), zircão, apatita e monazita. Dados geotermométricos quantitativos, obtidos da paragênese relacionada à foliação $\mathrm{Sn}$, fornecem temperatura no intervalo 660$680^{\circ} \mathrm{C}$ para a deformação do protomilonito-gnaisse Carlos Chagas (Castañeda et al., em preparação). Os processos de alteração são incipientes e posteriores à deformação regional, manifestando-se como sericitização de feldspato potássico, saussuritização de plagioclásio e cloritização de biotita.

O milonito-gnaisse tem a mesma composição mineralógica do protomilonito-gnaisse, mas a relação porfiroclastos/matriz é menor (i.e., a cominuição dos fenocristais foi maior), os porfiroclastos são mais estirados e a rocha é mais fitada (i.e., textura augen tende a dar lugar à ribbon). O sillimanita-granada ultramilonito tem granulação fina a média e tende a ser livre de biotita, mas contém os outros minerais presentes nos demais termos miloníticos. Sua foliação se caracteriza pelo forte estiramento de quartzo, feldspato, sillimanita e granada (Figuras 5 e 6). Feições de deformação intracristalina nos minerais félsicos, tais como extinção ondulante e deformação de maclas, tornam-se mais intensas e freqüentes no milonito e ultramilonito.

As paragêneses minerais e relações texturais demonstram que o processo de deformação milonítica ocorreu sincinematicamente ao metamorfismo regional de fácies anfibolito alto, cujo pico provavelmente atingiu a fácies granulito (indicada pela eliminação da biotita no ultramilonito).

A foliação Sn da Suíte Carlos Chagas deformada (G2cc) é a estrutura que controla a arquitetura tectônica da área focalizada, em decorrência do completo domínio territorial desta subunidade (Figura 1). A subunidade G2cc mostra raras dobras apertadas, mais visíveis onde se encontram xenólitos e porções ricas em biotita. A distribuição e atitudes das medidas de Sn evidenciam dois domínios que, aproximadamente, correspondem às folhas Ecoporanga e Mantena, situadas a norte e a sul do paralelo $18^{\circ} 30^{\prime} \mathrm{S}$, respectivamente (Figura 7). No domínio setentrional (Folha Ecoporanga), a foliação $\mathrm{Sn}$ tem mergulho predominantemente baixo a médio $\left(15^{\circ}\right.$ a $45^{\circ}$ ) para oeste, entre os azimutes 260 (WSW) e 340 (NNW). Localmente, a foliação mergulha para sul (180/ $30^{\circ}$ ) e nordeste $\left(20 / 20^{\circ}\right)$. No domínio meridional (Folha Mantena) predomina mergulho baixo a médio $\left(15^{\circ}\right.$ a $\left.60^{\circ}\right)$ para NW (azimute 340). No conjunto, os indicadores cinemáticos (e.g., porfiroclastos sigmoidais e/ou rotacionados, com caudas de recristalização e/ou sombras de pressão assimétricas) evidenciam movimento reverso, com transporte tectônico da capa genericamente rumo a leste.
O acervo de estruturas rúpteis é muito pobre na subunidade $\mathrm{G} 2 \mathrm{cc}$, assim como em toda a área enfocada, e se resume a fraturas esparsas, de mergulho íngreme, com direções a NW, NE e E-W. O conjunto de direção NW corresponde ao Lineamento VitóriaColatina-Ecoporanga. Estes sistemas de fraturas encaixam veios graníticos tardios e diques de diabásio (Figura 9F).

A Suíte Montanha apresenta diferenças composicionais e estruturais sutis em relação à Suíte Carlos Chagas, tais como maior conteúdo médio de biotita e melhor preservação em relação à deformação regional (Castañeda et al. 2006). O litotipo dominante na Suíte Montanha é um granito rico em grandes cristais de feldspato potássico macropertítico, geralmente foliado, localmente milonítico, de cor cinza e granulação grossa a muito grossa. A foliação apresenta mergulho médio em torno de $40^{\circ}-50^{\circ}$ para SW (azimute 235) e se superpõe concordantemente ao fluxo ígneo que orientou originalmente os fenocristais (se preservados da deformação) ou porfiroclastos de feldspato potássico. Os fenocristais ou porfiroclastos de feldspato potássico atingem $15 \mathrm{~cm}$ e predominam sobre a matriz. Ocorrem também fenocristais ou porfiroclastos centimétricos de granada. Rotação de porfiroclastos é comum nos termos deformados. Xenólitos estirados de paragnaisse são comuns. A matriz, inequigranular, consiste de quartzo, plagioclásio sódico, biotita e granada. Na matriz, os cristais maiores são de plagioclásio e granada. Zircão, apatita, titanita, ilmenita, sulfeto e magnetita são acessórios comuns. Sillimanita e muscovita primária são acessórios escassos. Embora a composição modal da matriz seja monzogranítica (Figura 3), sienogranito é a classificação adequada para a rocha como um todo, tendo em vista a marcante abundância de grandes cristais de feldspato potássico. Dados geotermobarométricos quantitativos indicam temperatura em torno de $640^{\circ} \mathrm{C}$ para a cristalização da paragênese associada à foliação Sn (Castañeda et al., em preparação).

\section{GRANITOGÊNESEG3}

Os produtos da granitogênese $\mathrm{G} 3$, do tipo $\mathrm{S}$, estão representados pela Suíte G3 que teve origem no estágio tardi a pós-colisional do Orógeno Araçuaí (PedrosaSoares \& Wiedemann-Leonardos 2000, Pedrosa-Soares et al. 2001, 2005). A rocha típica (mas, não exclusiva) da Suíte G3 é leucogranito com granada e/ou cordierita, livre da foliação Sn. Silva et al. (2005) apresentam idade de ca. $532 \mathrm{Ma}$ (U-Pb TIMS, zircão) para um corpo de leucogranito G3 que corta a Suíte Nanuque, próximo do limite norte da área aqui enfocada.

$\mathrm{Na}$ região mapeada, os veios e bolsões de leucogranito G3, assim como um corpo maior delimitado próximo a Poranga, estão encaixados em rochas das suítes Ataléia, Carlos Chagas e Montanha (Figura 1). As variedades de granito G3 são granada-cordierita 

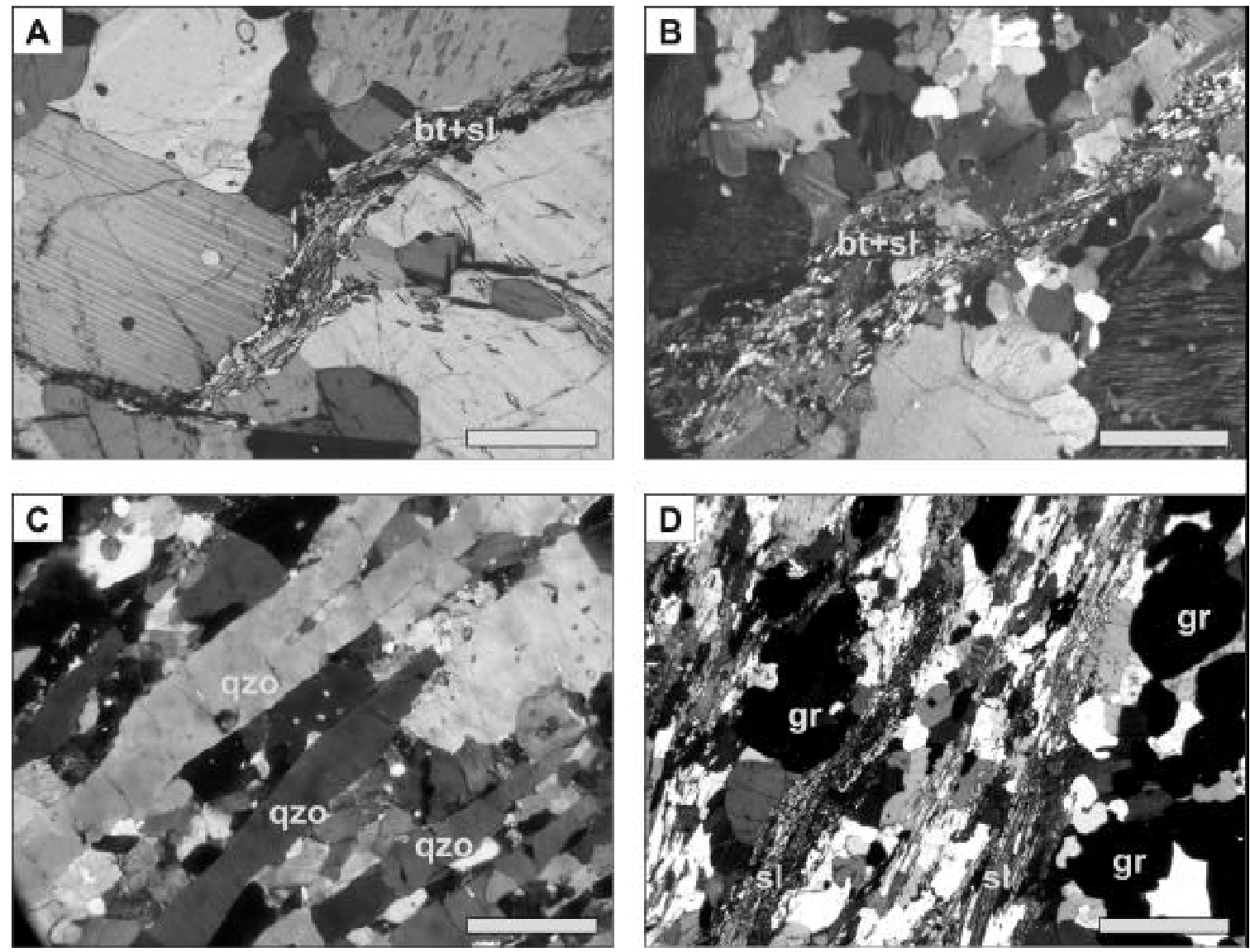

Figura 6. Fotomicrografias de rochas da Suíte Carlos Chagas (G2cc) ilustram a progressão da deformação em alta temperatura (a barra mede $1 \mathrm{~mm}$; polarizadores cruzados): A, trilha de biotita e sillimanita (bt+sl)

materializa a foliação Sn em matriz de protomilonito, cujos minerais félsicos arranjam-se em mosaico granoblástico; $B$, matriz de milonito com trilhas de biotita e sillimanita $(b t+s l)$ e subgranulação marcante dos minerais félsicos; $C$, fitas (ribbons) de quartzo (qzo) em ultramilonito; $D$, sillimanita-granada ultramilonito com trilhas de sillimanita (sl) e fitas de quartzo, paralelas às microbandas ricas em granada (gr).
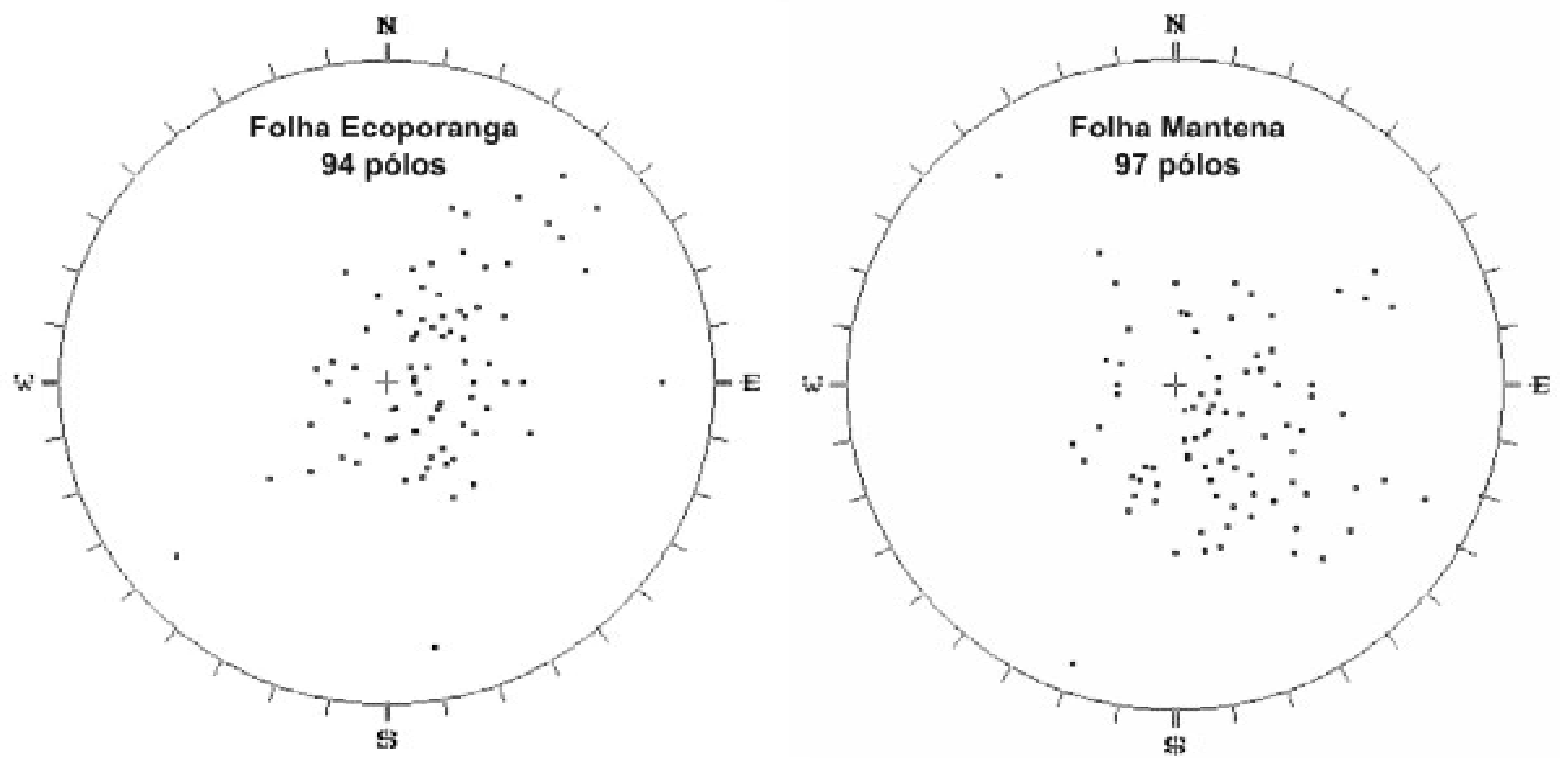

Figura 7. Diagramas de pólos (hemisfério inferior) da foliação Sn medida em afloramentos da Suite Carlos Chagas deformada (G2cc). 
leucogranito, granada leucogranito e cordierita leucogranito, de granulação média a grossa, textura porfirítica a subporfirítica, com fenocristais de granada e/ou cordierita. Estes leucogranitos são desprovidos da foliação regional, mas podem conter restos de granito G2 foliado (Figura 8). Feições de deformação intracristalina também estão ausentes dos minerais do leucogranito $\mathrm{G} 3$.

Os valores modais de quartzo ( 40 a $50 \%$ ) e feldspato potássico pertítico ( 40\%) são aproximadamente constantes no leucogranito G3. Os conteúdos de granada e cordierita são muito variáveis, embora subordinados. Os minerais acessórios são plagioclásio sódico livre, biotita, sillimanita, zircão, apatita, monazita e sulfeto. Pinitização de cordierita, cloritização de biotita e sericitização de feldspato potássico são incipientes.

As evidências petrográficas e estruturais indicam que os leucogranitos G3 são produtos autóctones a parautóctones da fusão parcial de granitos G2 deformados, em episódio pós-cinemático à foliação regional Sn. Evidências disto são as relações de corte e superposição de G3 em G2 e as presenças, em G3, de restos maiores e traços de foliação (schlieren) de G2, e de granada (com inclusões de fibrolita dobrada) herdada de G2. Aglomerados compostos quase exclusivamente por cordierita, granada e sillimanita representariam resíduos granulíticos de G3. Veios graníticos e pegmatitos, livres da foliação $\mathrm{Sn}$, encaixados no Complexo Nova Venécia, podem ser correlatos da Suíte G3, e representariam produtos da fusão parcial deste complexo.

Outra distinção da Suíte G3, na área mapeada, é a idade de 541 +/- $3 \mathrm{Ma}$ (U-Pb, monazita) obtida de uma amostra de leucogranito G3 (Medeiros in Castañeda et al. 2006), que é cerca de 35 Ma mais nova que granitos da Supersuíte G2. Diferença similar é registrada pelas datações U-Pb de amostras de G2 (ca. $573 \mathrm{Ma}$ ) e G3 ( $c a$. $532 \mathrm{Ma}$ ) de um mesmo afloramento dos arredores de Nanuque, cidade situada pouco a norte da área aqui enfocada (Silva et al. 2002, 2005). Além disso, dados geotermobarométricos indicam temperatura em torno de $800^{\circ} \mathrm{C}$ a $5 \mathrm{~kb}$, para a cristalização deste leucogranito G3. Este valor de temperatura é significativamente superior ao intervalo 640-680 ${ }^{\circ} \mathrm{C}$, registrado pelas suítes G2 (Castañeda et al. em preparação).
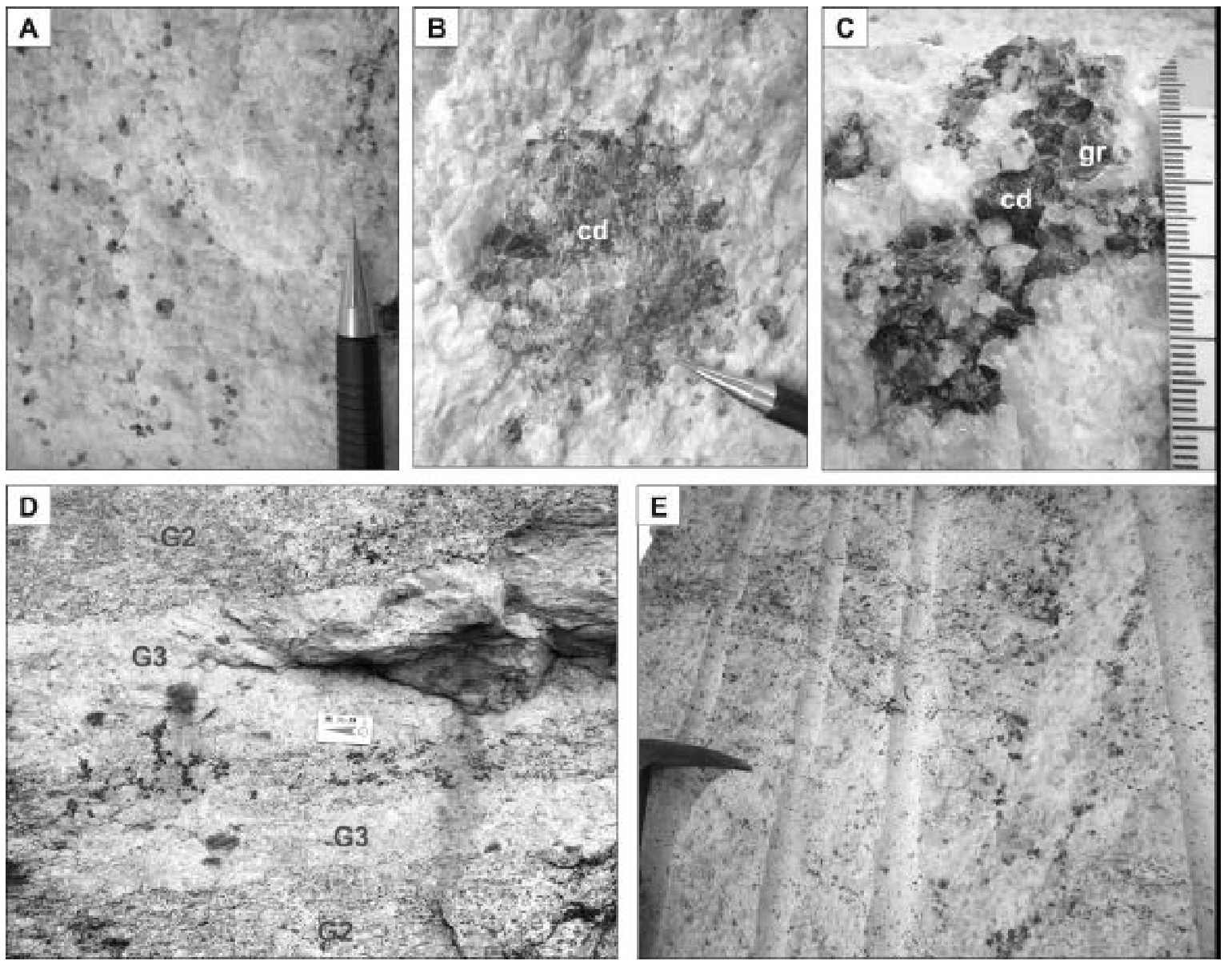

Figura 8. Fotografias de rochas da Suíte G3 e suas relações com representantes da Supersuíte G2. A, granada leucogranito; $B$, cordierita leucogranito (cd, cordierita) $C$, cordierita-granada leucogranito (cd, cordierita; gr, granada); D, veios de leucogranito G3 em afloramento da Suíte Carlos Chagas deformada (entre os veios de G3 ocorre resto de granito foliado G2 que foi parcialmente fundido; notar os contatos mal definidos desta banda); E, leucogranito $G 3$ com restitos (schlieren) de granito G2 foliado. 


\section{MAGMATISMOG5}

A Supersuíte G5 representa o plutonismo tardio, tipo I, do estágio pós-colisional ( ca. 520-490 Ma) do Orógeno Araçuaí. As intrusões G5 são livres da foliação regional Sn, e têm composições granítica e charnockítica, predominantes, com termos enderbíticos e mais básicos subordinados. O magmatismo G5 estaria relacionado ao colapso extensional do Orógeno Araçuaí (PedrosaSoares \& Wiedemann-Leonardos 2000, Pedrosa-Soares et al. 2001, 2005, Wiedemann et al. 2002, Campos et al. 2004, Martins et al. 2004, Mendes et al. 2005, Silva et al. 2005, Alkmim et al. 2006, Marshak et al. 2006).

Uma das subdivisões da Supersuíte G5 é a Suíte Aimorés (originalmente denominada por Silva et al. 1987). Na região mapeada, as intrusões da Suíte Aimorés são constituídas majoritariamente por biotita granito, charnockito e norito (Castañeda et al. 2006, Gradim et al. 2006, Pedrosa-Soares et al. 2006). A orientação geral dos corpos G5 sugere que o alojamento foi controlado pelo sistema de fraturas de direção NE, em particular no caso da grande intrusão de Barra de São Francisco que é flagrantemente discordante dos lineamentos NW (Sistema Vitória-Colatina), os quais estão nele representados por fraturas orientadas na direção N20W com mergulho médio de $45^{\circ}$ para NE. As intrusões G5 cortam as unidades mais velhas, mas tendem a condicionar a foliação das encaixantes paralelamente ao contato intrusivo (Figura 1).

Os corpos G5 de maior expressão na área mapeada são as intrusões de Barra do São Francisco, Águia Branca, Veloso (a leste de Conceição do Quinze), Cotaxé e Muritiba (a norte de Cotaxé; Figura 1). Os dois primeiros são predominantemente constituídos de biotita granito, a oeste, e de charnockito, a leste. Os corpos Cotaxé e Muritiba consistem de charnockito, com granito e norito subordinados, e Veloso parece ser largamente dominado por norito. A estrutura interna das intrusões G5 é isotrópica ou mostra orientação por fluxo ígneo (Figura 9). Localmente, ocorrem foliação de borda (decorrente do processo de colocação da intrusão) e fluxo ígneo de granulação fina, que podem ser confundidos com a foliação Sn em observação de campo. Autólitos intermediários a máficos e/ou xenólitos de encaixantes tendem a ser mais comuns rumo ao contato das intrusões. Metamorfismo de contato sobre as rochas encaixantes, evidenciado por recristalização mineral com obliteração da foliação Sn e fusão parcial localizada, pode ocorrer na proximidade de corpos G5.

Duas fácies de biotita granito foram identificadas em corpos da Suíte Aimorés, na área mapeada (Castañeda et al. 2006, Pedrosa-Soares et al. 2006). O biotita granito de granulação grossa geralmente tem textura porfirítica e coloração cinza, com fenocristais de feldspato potássico pertítico (Figura 9A). Fenocristais e eventuais autólitos ricos em biotita podem estar orientados por fluxo ígneo. A composição mineralógica essencial consiste de feldspato potássico pertítico, plagioclásio sódico, quartzo e biotita. Os minerais acessórios são apatita, zircão, allanita e opacos. Veios pegmatíticos a biotita e berilo representam resíduos deste granito. $\mathrm{O}$ biotita granito de granulação fina a média ocorre como veios e fácies de borda de intrusões G5, e como diques e soleiras encaixadas em unidades mais velhas (Figura 9C, E e F). Sua textura varia de equigranular a porfirítica com fenocristais de feldspato potássico. É composto essencialmente por microclina, plagioclásio sódico e biotita. Os minerais acessórios são apatita, zircão e opacos.

O charnockito tem textura porfirítica a subporfirítica, de granulação grossa a média e estrutura geralmente isotrópica (Figura 9B). Sua coloração varia entre verde escuro, verde claro e verde azulado, quando livre de intemperismo. Se intemperizada, esta rocha tende a mudar de cor, passando gradativamente a verde amarelado, amarelo escuro, bege e cinza. $O$ charnockito é composto de feldspato potássico pertítico, quartzo, plagioclásio, biotita, ortopiroxênio e anfibólio. A granada pode ser muito abundante próximo aos contatos das intrusões, ou em zonas restritas no seu interior, em função de assimilação de rochas encaixantes peraluminosas. Os minerais acessórios comuns são zircão, titanita, apatita, espinélio e opacos.

O norito é uma rocha equigranular fina, com estrutura isotrópica e cor verde escura a negra (Figura 9D). Sua composição mineralógica essencial consiste de labradorita $(\sim 70 \%)$ e ortopiroxênio $(\sim 15 \%)$, com quartzo ( $5 \%$ ), biotita $(£ 5 \%$ ) e minerais opacos subordinados.

As relações de campo sugerem que as fácies graníticas e charnockíticas formaram-se no mesmo episódio magmático (Castañeda et al. 2006, PedrosaSoares et al. 2006). De fato, datações U-Pb sobre amostras da área mapeada demonstram que a cristalização magmática destas rochas ocorreu em torno de 505-490 Ma. O charnockito de Barra de São Francisco tem idade de 506 +/- 18 Ma (zircão, U-Pb SHRIMP; Jacobsohn 2006) e o hornblenda-biotita granito da intrusão de Cotaxé foi datado em 492 +/- 9 Ma (zircão, U-Pb TIMS; Medeiros in Castañeda et al. 2006).

\section{CONCLUSÃO}

A região oriental do Orógeno Araçuaí é um excelente laboratório natural para se estudar a crosta intermediária, onde processos anatéticos e plutonismo granítico são muito expressivos. Em particular, nas regiões leste e nordeste de Minas, norte do Espírito Santo e extremo sul da Bahia estão expostos grandes maciços de paragnaisses migmatizados e de granitos do tipo $S$ que, virtualmente, simbolizam um "mar de anatexia" (PedrosaSoares \& Wiedemann-Leonardos 2000, Pedrosa-Soares et al.2001, 2005). O presente artigo, fundamentado em mapeamento de campo sobre cerca de 1200 afloramentos rochosos, é uma contribuição a esta linha de estudos.

Dentre os grandes conjuntos magmáticos do Orógeno Araçuaí, apenas dois estão ausentes da região mapeada: a Supersuíte G1 que representa o arco magmático pré-colisional (ca.630-585 Ma); e a Suíte G4 que engloba intrusões tipo $\mathrm{S}$, relativamente rasas, póscolisionais (ca. 530-500 Ma), (Pedrosa-Soares \& 

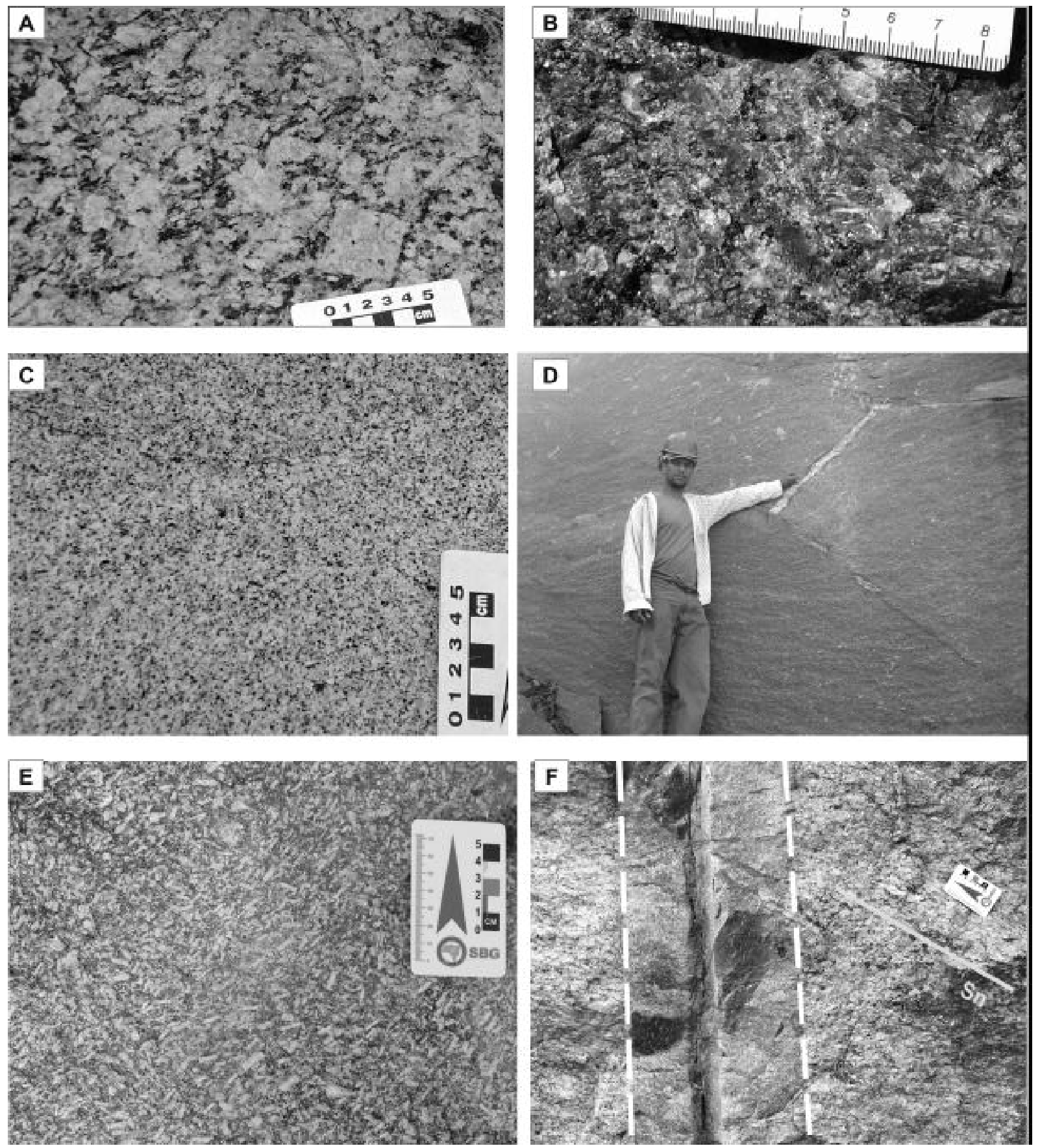

Figura 9. Fotografias de rochas da Suíte Aimorés. A, B e C, biotita granito grosso, charnockito e biotita granito fino da intrusão de Barra do São Francisco, respectivamente; D, norito de Cotaxé com veio de quartzo (branco); E, biotita granito porfirítico com fluxo ígneo; $F$, veio de biotita granito fino discordante da foliação Sn do protomilonito-gnaisse da Suíte Carlos Chagas.

Wiedemann-Leonardos 2000, Pedrosa-Soares et al. 2001, 2005).

O esquema evolutivo sumarizado adiante se refere aos episódios magmáticos G2, G3 e G5 na região aqui enfocada, mas pode ser aplicável a todo o setor oriental do Orógeno Araçuaí (ver referências bibliográficas nos itens anteriores):

- O primeiro episódio anatético do tipo $\mathrm{S}$ (granitogênese G2) originou os protolitos magmáticos das suítes Ataléia, Carlos Chagas e Montanha, durante o estágio sincolisional do Orógeno Araçuaí. Estas suítes representam ou incluem fusões derivadas do Complexo Nova Venécia e seus correlatos (e.g., Jequitinhonha). Estes complexos, ricos em gnaisses peraluminosos, ocupam extensa região fora da área mapeada e atingiram condições metamórficas (800$900^{\circ} \mathrm{C}$ a 5,5-6,5 kb), sincinemáticas a Sn, perfeitamente adequadas à produção de grande volume de magma granítico. A foliação regional $\mathrm{Sn}$ se implantou nos granitos G2, preferencialmente ao longo do fluxo ígneo, à medida que eles se cristalizaram, em torno de $575 \mathrm{Ma}$, à temperatura de $640-680^{\circ} \mathrm{C}$. 
- O segundo episódio anatético do tipo $\mathrm{S}$ (granitogênese G3) incidiu sobre as suítes graníticas deformadas (G2) e sobre o Complexo Nova Venécia, após cessar o estágio de implantação da foliação regional. Este episódio originou o leucogranito G3 e correlatos, livres da foliação $\mathrm{Sn}$, em torno de 540-530 Ma, à temperatura de $c a .800^{\circ} \mathrm{C} \mathrm{a} 5 \mathrm{~kb}$ (ou seja, em regime de descompressão regional relativamente às suítes G2).

- O terceiro episódio magmático foi do tipo I, envolveu contribuição mantélica e teve lugar em torno de $500 \mathrm{Ma}$, durante o estágio pós-colisional do Orógeno Araçuaí (ca. 520-490 Ma). Neste episódio originaramse as intrusões G5, compostas de granito, charnockito e/ou norito, também desprovidas da foliação regional Sn. Os dois grandes sistemas de fraturas (NW ou Sistema Vitória-Colatina e NE) estariam relacionados ao colapso extensional do Orógeno Araçuaí e seriam sítios privilegiados para conduzir e alojar as intrusões G5.

A foliação Sn das suítes G2 (Ataléia, Carlos Chagas e Montanha) tem características marcantes e onipresentes de foliação em estado sólido (solid state foliation), geralmente milonítica; em contraste com o que sugerem Vauchez et al. (2003) e Pinto \& EgydioSilva (2006). Entretanto, esta foliação originou-se sob temperaturas em torno do limite mínimo para fusão granítica $\left(640-680^{\circ} \mathrm{C}\right)$. Isto permitiria convivência da deformação com quantidade muito pequena de fase ígnea, mas que, como demonstram a maioria das evidências (Figuras 4, 5 e 6), seria insuficiente para atribuir caráter magmático à foliação $\mathrm{Sn}$.

Como é de se esperar para corpos homogêneos de dimensão avantajada, partes das grandes massas ígneas G2 foram poupadas da deformação regional, a exemplo da unidade composta de granada-biotita leucogranito, livre de Sn, que se inclui na Suíte Carlos Chagas indeformada (G2cci). Contudo, na análise das relações entre deformação e fases ígneas, se deve atentar para a distinção entre as fases graníticas livres de Sn, uma vez que as fusões G3 representam episódio anatético significativamente mais novo que a granitogênese G2. Para tal análise contribuem as marcantes diferenças composicionais e estruturais exibidas pelos granitos $\mathrm{G} 2$ eG3.

A progressiva eliminação da biotita, dando lugar a sillimanita, do protomilonito ao ultramilonito da Suíte Carlos Chagas, evidencia deformação sob temperatura crescente, sem necessariamente implicar em aumento de pressão. Isto poderia ser o prenúncio do aumento de temperatura que, posteriormente, promoverá o aparecimento das fusões $\mathrm{G} 3\left(800^{\circ} \mathrm{C}\right)$, em regime de descompressão $(5 \mathrm{~kb})$, após cessar a deformação regional.

Como sugere o acervo geocronológico disponível, entre o metamorfismo do Complexo Nova Venécia e granitogênese $\mathrm{G} 2$ até as últimas intrusões G5 decorreu um intervalo de cerca de 100 milhões de anos. Durante este tempo, os episódios de plutonismo (incluindo fusão parcial, migração, alojamento e resfriamento das massas ígneas) durariam de 10 a $30 \mathrm{Ma}$. No conjunto, isto implica que áreas significativas do setor oriental do Orógeno
Araçuaí permaneceram a temperaturas em torno ou acima do mínimo para a fusão granítica $\left(\mathrm{ca} .650^{\circ} \mathrm{C}\right)$ por longo período de tempo ( $c a .100 \mathrm{Ma}$ ). Tal permanência em alta temperatura seria heterogênea em distribuição espacial, de tal modo a provocar desequilíbrios químico e isotópico em intensidades diferentes nos minerais. Ainda assim, observa-se uma tendência à concentração de datações U-Pb (particularmente de zircão) em intervalos de tempo definidos; o que também parece acontecer com dados geotermobarométricos obtidos de paragêneses bem caracterizadas em relação à deformação.

Se considerarmos o Orógeno Araçuaí e sua contraparte de baixo grau metamórfico na África (Faixa Congo Ocidental), a seguinte questão é particularmente intrigante:

- Como explicar a enorme quantidade de calor necessária para promover o metamorfismo regional de alto grau e dar origem ao imenso volume de fusões graníticas tipo $\mathrm{S}$ (G2 e G3)?

A resposta estaria relacionada ao sítio geotectônico abordado, uma região de retroarco de orógeno continental. Estudos de orógenos recentes mostram que bacias retroarco são particularmente quentes, porque apresentam embasamento adelgaçado e experimentam significativa ascensão de astenosfera em convecção, durante o estágio pré-colisional (acrescionário) do orógeno. Por isto, são zonas de grande fraqueza litosférica destinadas a se tornar intensamente móveis durante o estágio colisional da orogenia. Por sua vez, o espessamento crustal, decorrente do empilhamento de grandes lascas de empurrão, promove aumento da carga radioativa, resultando em incremento térmico. Embora tais modelos (e.g., Thompson et al. 2001, Collins 2002, Hyndman et al. 2005) apresentem diferentes concepções para a causa do calor orogênico, eles justificam a manutenção de altas temperaturas por muitas dezenas de milhões de anos na região de retroarco. Neste sentido, a questão acima colocada seria respondida por uma combinação de fatores: i) o calor requerido pelo metamorfismo sincinemático a Sn no Complexo Nova Venécia e para a granitogênese G2 (ca. 585-560 Ma) seria herdado da ascensão astenosférica na zona de retroarco, com alguma contribuição do espessamento crustal; ii) o calor necessário para a granitogênese G3 (ca. 540-530 Ma) seria fornecido essencialmente pela desintegração dos elementos radioativos da pilha crustal espessada, sob regime de descompressão regional.

Por sua vez, o calor requerido para dar origem à Supersuíte G5 (ca. 520-490 Ma), que inclui componentes mantélicos, estaria ligado a processo muito diferente dos acima mencionados. Neste caso, a ascensão de magma mantélico ao longo das zonas de fraqueza (e.g., Sistema Vitória-Colatina), associadas ao colapso extensional do Orógeno Araçuaí, promoveria a fusão da crosta profunda, resultando nas misturas de magmas que compõem os plutons G5. 


\section{AGRADECIMENTOS}

Este artigo é uma contribuição científica resultante do Contrato CPRM-UFMG (Programa Geologia do Brasil-MME-CPRM-Universidades) e de estudos realizados no âmbito de projetos financiados por CNPq e FINEP. Os autores bolsistas agradecem ao CNPq, CAPES, PRODOC-CAPES, FAPEMIG e FAPERJ. Agradecemos a Luiz Carlos da Silva (CPRM), Renato Moraes (USP) e Carlos Alberto Rosière (UFMG) pelas proveitosas discussões; a Sônia Greco (GRANASA), Antônio Carneiro e Luiz Ferreira (MINERACAN), e Cícero Dutra, pelas facilidades de acesso a pedreiras; e a dois revisores anônimos de GEONOMOS.

\section{REFERÊNCIAS BIBLIOGRÁFICAS}

Alkmim, F.F., Marshak, S., Pedrosa-Soares, A.C., Peres, G.G., Cruz, S.C.P., Whittington, A., 2006. Kinematic evolution of the Araçuaí - West Congo orogen in Brazil and Africa: Nutcracker tectonics during the Neoproterozoic assembly of Gondwana. Precambrian Research, 149: 43-64.

Campos, C., Mendes, J. C., Ludka, I.P., Medeiros, S.R., Moura, J.C., Wallfass, C. 2004. A review of the Brasiliano magmatism in Southern Espírito Santo, Brazil, with emphasis on postcollisional magmatism. Journal of the Virtual Explorer, 17 (online).

Castañeda, C., Pedrosa-Soares, A.C., Belém, J., Vieira, V.S., Queiroga, G. (em preparação). Geothermobarometry of metapelites and granites from the northern Araçuaí Orogen: implications for PTt paths in a confined orogen.

Castañeda, C., Pedrosa-Soares, A.C., Belém, J., Gradim, D., Dias, P.H.A., Medeiros, S.R., Oliveira, L. 2006. Mapa Geológico e Nota Explicativa da Folha Ecoporanga, 1:100.000. In: Folha Ecoporanga. Programa Geologia do Brasil, Contrato CPRM-UFMG, CD-ROM.

Collins, W.J. 2002. Hot orogens, tectonic switching, and creation of continental crust. Geology, 30: 535-538.

Cordani U.G. 1973. Evolução Geotectônica da Região Costeira do Brasil, entre Salvador e Vitória. Tese de Livre Docência, Instituto de Geociências, Universidade de São Paulo, 98 p.

Gradim, C.T., Queiroga, G.N., Roncato, J.G., Novo, T.A., PedrosaSoares, A.C. 2006. Mapa Geológico da Folha Mantena, escala 1:100.000. In: Folha Mantena. Programa Geologia do Brasil, Contrato CPRM-UFMG, CD-ROM.

Gradim, C.T. (em preparação). Caracterização do Complexo Nova Venécia na área-tipo, e sua relação com episódios de granitogênese do Orógeno Araçuaí. Dissertação de Mestrado, Instituto de Geociências da UFMG, Belo Horizonte.

Heilbron, M., Pedrosa-Soares, A.C., Campos-Neto, M.C., Silva, L.C., Trouw, R., Janasi, V.A. 2004. Província Mantiqueira. In: V. Mantesso-Neto, A. Bartorelli, C.D.R. Carneiro, B.B. Brito-Neves (org.), Geologia do Continente Sul-Americano. São Paulo, Editora Beca, cap. XIII, p. 203-234.

Hyndman, R., Currie, C.A., Mazzotti, S.P. 2005. Subduction zone backarcs, mobile belts, and orogenic heat. GSA Today, 15: 4-10.

Jacobsohn, T. 2006. Comportamento dos sistemas isotópicos em processos tectono-metamórficos de médio e alto grau: Faixa Araçuaí, MG-ES. Tese de Doutoramento (em conclusão), Instituto de Geociências da USP, São Paulo.

Martins, V.T.S., Teixeira, W., Noce, C.M., Pedrosa-Soares, A.C. 2004. Sr and Nd characteristics of Brasiliano/Pan-African granitoid plutons of the Araçuaí Orogen, Southeastern Brazil: Tectonic implications. Gondwana Research, 7: 75-89.

Marshak, S., Alkmim, F.F., Whittington, A.G., Pedrosa-Soares, A.C. 2006. Extensional collapse in the Neoproterozoic Araçuaí orogen, eastern Brazil: a setting for reactivation of asymmetric crenulation cleavage. Journal of Structural Geology, 28: 129-147.
Mendes, J.C., Medeiros, S.R., McReath, I. 2005. CambroOrdovician Magmatism in SE Brazil: U-Pb and Rb-Sr Ages, Combined with $\mathrm{Sr}$ and $\mathrm{Nd}$ isotopic data of charnockitic rocks from Várzea Alegre Complex. Gondwana Research, 8: 337349 .

Munhá, J.M.U, Cordani, U.G., Tassinari, C.C.G, Palácios, T. 2005. Petrologia e termocronologia de gnaisses migmatíticos da Faixa de Dobramentos Araçuaí (Espírito Santo, Brasil). Revista Brasileira de Geociências, 35(1): 123-134.

Nalini Jr, H.A., Bilal, E.; Correia-Neves, J.M. 2000. Syncollisional peraluminous magmatism in the Rio Doce region: mineralogy, geochemistry and isotopic data of the Urucum suite (eastern Minas Gerais state, Brazil). Revista Brasileira de Geociências, 30(1): 120-125.

Noce, C.M., Macambira, M.B., Pedrosa-Soares, A.C. 2000. Chronology of Neoproterozoic-Cambrian granitic magmatism in the Araçuaí Belt, Eastern Brazil, based on single zircon evaporation dating. Revista Brasileira de Geociências, 30(1): 25-29.

Noce, C.M., Pedrosa-Soares, A.C., Piuzana, D., Armstrong, R., Laux, J.H., Campos, C.M., Medeiros, S.R. 2004. Ages of sedimentation of the kinzigitic complex and of a late orogenic thermal episode in the Araçuaí orogen, Northern Espírito Santo State, Brazil: Zircon and monazite $\mathrm{U}-\mathrm{Pb}$ SHRIMP and ID-TIMS data. Revista Brasileira de Geociências, 34:587-592.

Pedrosa-Soares, A.C. \& Wiedemann-Leonardos, C.; 2000. Evolution of the Araçuaí Belt and its connection to the Ribeira Belt, eastern Brazil. In: U.G Cordani, E.J. Milani, A. Thomaz-Filho, D.A. Campos, D.A. (orgs), Tectonic Evolution of South America. SBG, São Paulo, p. 265-285.

Pedrosa-Soares A.C., Noce C.M., Wiedemann C., Pinto C.P. 2001. The Araçuaí-West-Congo Orogen in Brazil: An overview of a confined orogen formed during Gondwanaland assembly. Precambrian Research. 110:307-323.

Pedrosa-Soares, A.C., Noce, C. M., Silva, L.C., Cordani, U., Alkmim, F.F., Babinski, M. 2005. Orógeno Araçuaí: estágio atual do conhecimento geotectônico. In: Simpósio Cráton do São Francisco, 3, Salvador. SBG, Anais, p. 243-246.

Pedrosa-Soares, A.C., Queiroga, G.N., Gradim. C.T., Roncato, J.G., Novo, T.A., Jacobsohn, T., Silva, K.L. 2006. Nota Explicativa da Folha Mantena, 1:100.000. In: Folha Mantena. Programa Geologia do Brasil, Contrato CPRMUFMG, CD-ROM.

Pinto, C.P., Drumond, J.B.V., Féboli, W.L. (coord.) 2001. Projeto Leste. CPRM-COMIG, Belo Horizonte, CD-ROM.

Pinto, M.T. \& Egydio-Silva, M. 2006. O complexo anatético Carlos Chagas na região de Barra do São Francisco e Ecoporanga (ES): um estudo petrográfico e tectônico. In: Congresso Brasileiro de Geologia, 33, Aracaju. SBG, Anais, p. 114.

Siga Jr., O. 1986. A evolução geocronológica da porção nordeste de Minas Gerais, com base em interpretações geocronológicas. Dissertação de Mestrado, Instituto de Geociências da USP, São Paulo, 140 p.

Silva, J.M.R, Lima, M.I.C., Veronese, V.F., Ribeiro Junior, R.N. \& Siga-Júnior, O. 1987. Geologia. In: PROJETO RADAMBRASIL. Folha SE.24 Rio Doce. IBGE, Rio de Janeiro, 1987 (Levantamento de Recursos Naturais, 34).

Silva, J.N. \& Ferrari, P.G. 1976. Projeto Espírito Santo; relatório final. Belo Horizonte, DNPM/CPRM, 1976. 408p. (Relatório do arquivo técnico da DGM, 2596).

Silva, L.C., Armstrong, R., Noce, C.M., Carneiro, M.A., Pimentel, M.M., Pedrosa-Soares, A.C., Leite, C.A., Vieira, V.S., Silva, M.A., Paes, V.J.C.; Cardoso-Filho, J.M. 2002. Reavaliação da evolução geológica em terrenos précambrianos brasileiros com base em novos dados $\mathrm{U}-\mathrm{Pb}$ SHRIMP, parte II: Orógeno Araçuaí, Cinturão Mineiro e Cráton São Francisco Meridional. Revista Brasileira de Geociências, 32: 513-528.

Silva, L.C., Mcnaughton, N.J., Armstrong, R., Hartmann, L.A., Fletcher, I. 2005. The Neoproterozoic Mantiqueira Province and its African connections: a zircon-based $\mathrm{U}-\mathrm{Pb}$ geochronologic subdivision for the Basiliano/Pan-African 
systems of orogens. Precambrian Research, 136: 203-240.

Thompson, A.B., Schulmann, K., Jezek, J., Tolar, V. 2001. Thermally softened continental extension zones (arcs and rifts) as precursors to thickened orogenic belts. Tectonophysics, 332: 115-141.

Vauchez, A., Egydio-Silva, M., Tommasi, A., Uhlein, A. 2003. The Ribeira/Araçuaí migmatitic-magmatic allochton, an equivalent of the southern Tibet "crustal astenosphere". In: EGS-AGU-EUG Joint Assembly, Nice, 2003. Geophysical Research Abstracts, v. 5, 11581 .

Wiedemann, C.M., Medeiros, S.R., Mendes, J.C., Ludka, I.P., Moura, J.C. 2002. Architecture of Late Orogenic Plutons in the Aracuaí-Ribeira Folded Belt, Southeast Brazil. Gondwana Research, 5(2): 381-399. 